\title{
PENGARUH KELEMBAPAN, SUHU UDARA DAN CURAH HUJAN TERHADAP KEJADIAN KEBAKARAN GAMBUT DI KABUPATEN TANJUNG JABUNG TIMUR, JAMBI
}

\author{
(The effect of humidity, temperature and precipitation to peat fire occurrences in Tanjung Jabung \\ Timur Regency, Jambi)
}

\author{
Erianto Indra Putra ${ }^{*}$, dan Idelia Lathiifah Puspadewi ${ }^{1}$
}

(Diterima Oktober 2020/Disetujui Desember 2020)

\begin{abstract}
Tanjung Jabung Timur Regency, Jambi has a serious problem with peatlands fires. The effects of humidity, air temperature and rainfall are often associated with climatic influences that provide ideal conditions for fire to occur. The results of the study clearly showed that air humidity, air temperature, and rainfall contributed to the number of hotspot. Humidity was the variable with highest correlation of -0,569. The decrease of humidity that followed by a decrease in rainfall and an increase in air temperature from June to September 2019 led to the highest hotspot in September 2019, which resulted to an increase of forest fire occurrences in Tanjung Jabung Timur, Jambi.
\end{abstract}

Keywords: fire, peatlands, temperature, rainfall, humidity.

\section{PENDAHULUAN}

Provinsi Jambi merupakan provinsi yang memiliki lahan gambut ke-3 terluas di pulau Sumatera. Luas area lahan gambut di Provinsi Jambi mencapai 736.227,20 ha atau sekitar 14\% dari luas Provinsi Jambi. Lahan gambut ini tersebar di enam kabupaten, yaitu Kabupaten Tanjung Jabung Timur seluas 311.992,10 ha, Kabupaten Muaro Jambi seluas 229.703,90 ha, Kabupaten Tanjung Jabung Barat seluas 154.598,00 ha, Kabupaten Sarolangun seluas 33.294,20 ha, Kabupaten Merangin seluas 5.809,80 ha, dan Kabupaten Tebo seluas 829,20 ha. (Nurjanah et al. 2013).

Kabupaten Tanjung Jabung Timur termasuk daerah yang rawan kebakaran karena didominasi oleh tanaman sawit dan tanah gambut (Pemerintah Kabupaten Tanjung Jabung Timur 2020). Kebakaran terakhir terjadi pada tahun 2019 dengan luasan areal yang terbakar mencapai 100 ha di Sinarwajo Kecamatan Mendahara Ulu Kabupaten Tanjung Jabung Timur Jambi (Tambunan 2019). Hal ini telah menjadi ancaman serius terhadap keberadaan dan kelestarian gambut.

Iklim merupakan salah satu faktor alami yang dapat mendukung terjadinya suatu kebakaran hutan, karena kondisi iklim (suhu, kelembaban, curah hujan, kecepatan angin) dapat mempengaruhi tingkat kekeringan bahan bakar permukaan, banyaknya oksigen yang ada, dan kecepatan penyebaran api (Syaufina 2008). Peramalan atau deteksi dini kebakaran dapat diketahui dengan bantuan alat yang telah dikembangkan. Satelit Terra dan Aqua melalui sensor MODIS (Moderate Resolution Imaging Spectroradiometer) dapat digunakan untuk

\footnotetext{
${ }^{1}$ Departemen Silvikultur, Fakultas Kehutanan dan Lingkungan, Institut Pertanian Bogor

* Penulis korespondensi:

e-mail: eriantopu@apps.ipb.ac.id
}

mengetahui data titik panas (hotspot) pada suatu lokasi tertentu pada saat tertentu.. Informasi titik panas (hotspot) dapat memberikan informasi awal mengenai indikasi terjadinya kebakaran (Saharjo dan Velicia 2018). Informasi titik panas melalui pengindraan satelit perlu dilakukan secara berkelanjutan sebagai deteksi awal terjadinya kebakaran hutan dan lahan sehingga dampak negatif yang ditimbulkan dapat diminimalisir.

Perubahan iklim yang terjadi perlu dianalisis pengaruhnya terhadap potensi kebakaran di wilayah Kabupaten Tanjung Jabung Timur Jambi. Oleh karena itu, perlu dilakukan penelitian untuk mengetahui adanya pengaruh dari unsur iklim, terutama kelembapan, suhu udara dan curah hujan terhadap terjadinya kebakaran lahan gambut-dengan mencari hubungan antara hotspot dengan kondisi kelembapan, suhu udara dan curah hujan sebagai indikator terjadinya kebakaran lahan gambut.

\section{METODE PENELITIAN}

\section{Waktu dan Tempat Penelitian}

Penelitian ini dilaksanakan selama 3 bulan yaitu pada bulan Maret - Mei 2020. Lokasi penelitian yaitu di Kabupaten Tanjung Jabung Timur Provinsi Jambi. Pengolahan data dilakukan di Laboratorium Kebakaran Hutan dan Lahan, Departemen Silvikultur Fakultas Kehutanan dan Lingkungan IPB.

\section{Alat dan Bahan}

Alat yang digunakan dalam penelitian ini adalah software Microsoft office, Arc Map GIS 10.3. Bahan yang digunakan dalam penelitian ini yakni menggunakan peta administrasi Kabupaten Tanjung Jabung Timur, data 
sebaran hotspot tahun 2017-2019 yang diperoleh dari MODIS Katalog LAPAN, data curah hujan harian yang diperoleh melalui satelit TRMM, data kelembapan udara dan suhu udara periode 2017-2019 dari Badan Meteorologi, Klimatologi, dan Geofisika (BMKG) dan peta administrasi Jambi yang diperoleh dari website tanahair.indonesia.go.id.

\section{Analisis Data}

Analisis data yang dilakukan dalam studi ini adalah analisis deskriptif dan analisis korelasi. Pengunduhan hotspot harian pada MODIS Katalog LAPAN Provinsi Jambi dilakukan untuk periode 2017-2019. Hasil pengunduhan hotspot harian kemudian dipetakan menjadi peta sebaran hotspot pixel lokasi studi yang telah dioverlay dengan peta HLG Sungai Buluh menggunakan Arc Map GIS 10.3.

Data curah hujan harian Provinsi Jambi diunduh dari NASA menggunakan satelit TRMM (Tropical Rainfall Measuring Mission) pada tahun 2017-2019. Kemudian data curah hujan harian diolah menggunakan Arc Map GIS 10.3 untuk mencari nilai curah hujan pada pixel yang mencakup lokasi studi. Setelah itu data curah hujan direkapitulasi perbulan dan pertahun.

Data kelembapan udara dan suhu udara didapatkan dengan mengunduh di Badan Meteorologi, Klimatologi, dan Geofisika (BMKG) kemudian data kelembapan dan suhu udara direkapitulasi perbulan dan pertahun.

\section{HASIL DAN PEMBAHASAN}

\section{Kondisi Umum}

Kabupaten Tanjung Jabung Timur secara geografis terletak pada $0^{\circ} 53^{\prime}-1^{\circ} 41^{\prime}$ LS dan $103^{\circ} 23-104^{\circ} 31 \mathrm{BT}$, mempunyai ketinggian berkisar antara 1-5 mdpl serta total luas wilayah 544.500,00 ha. Kabupaten Tanjung Jabung Timur termasuk daerah yang rawan kebakaran karena didominasi oleh tanaman sawit dan tanah gambut.

Iklim di Kabupaten Tanjung Jabung Timur Jambi berdasarkan Zona Agroklimat B 1 dengan 8 bulan basah (bulan dengan curah hujan $>200 \mathrm{~mm}$ ) dan 2 bulan kering (bulan dengan curah hujan $<100 \mathrm{~mm}$ ) berturut-turut. Bulan basah terjadi pada bulan Oktober sampai April, sedangkan bulan kering terjadi mulai bulan Juni sampai

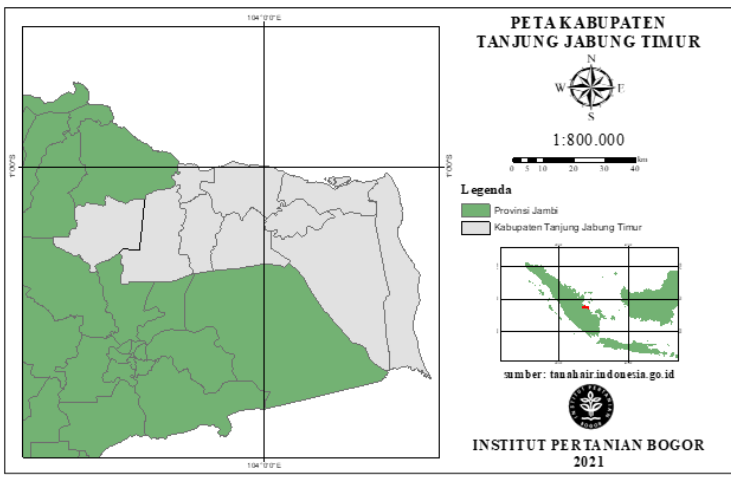

Gambar 1 Peta Kabupaten Tanjung Jabung Timur Provinsi Jambi
Agustus (Pemerintah Kabupaten Tanjung Jabung Timur, 2020). Peta Kabupaten Tanjung Jabung Timur Jambi terdapat pada Gambar 1.

\section{Kelembapan Udara}

Kelembapan udara tertinggi dalam kurun waktu 2017-2019 adalah pada bulan Februari 2019 dengan nilai sebesar $89,3 \%$ dan kelembapan terendah pada bulan September 2019 dengan nilai sebesar 76,8\%. Grafik ratarata kelembapan udara bulanan pada Gambar 2 menunjukkan adanya penurunan kelembapan udara dalam kurun waktu 3 tahun di Kabupaten Tanjung Jabung Timur Jambi.

\section{Suhu Udara}

Secara klimatologis, wilayah Kabupaten Tanjung Jabung Timur Jambi beriklim basah hujan hampir sepanjang tahun atau kurang lebih 8-10 bulan basah dan bulan kering 2-4 bulan dengan rata-rata suhu udara 25,5$28,3^{\circ} \mathrm{C}$. Perputaran iklim dan cuaca ada dua, yaitu musim kemarau dan musim penghujan. Musim kemarau biasanya jatuh pada bulan Agustus hingga Desember, sedangkan musim penghujan jatuh di bulan Januari hingga Juli pada tiap tahunnya.

Gambar 3 memperlihatkan rata-rata suhu udara bulanan rentang tahun 2017-2019 menunjukkan bahwa suhu tertinggi terjadi pada bulan Agustus 2019 sebesar $27,6^{\circ} \mathrm{C}$ dan suhu terendah pada bulan Desember 2018 sebesar $26,0^{\circ} \mathrm{C}$.

\section{Curah Hujan}

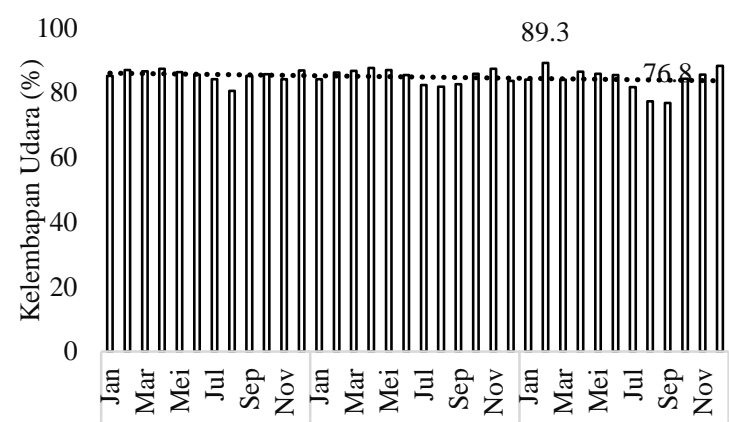

Gambar 2 Kelembapan udara bulanan Tanjung Jabung Timur tahun 2017-2019

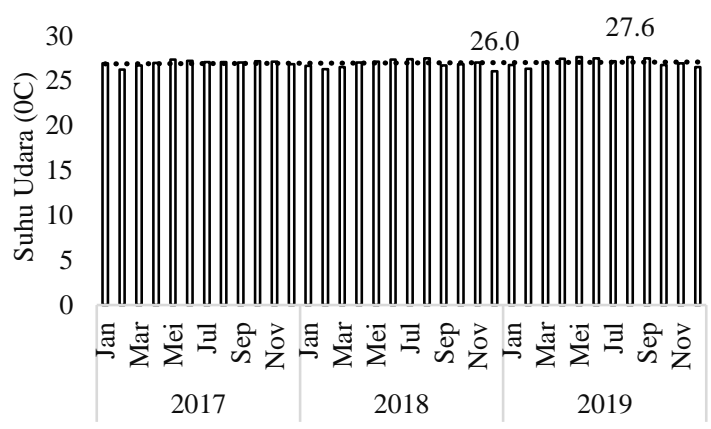

Gambar 3 Rata-rata suhu udara bulanan Tanjung Jabung Timur tahun 2017-2019 
Curah hujan bulanan tertinggi Tanjung Jabung Timur Jambi terdapat pada bulan April 2017 sebesar 464,7 mm, sementara terendah terdapat pada bulan Agustus 2019 sebesar 11,4 mm. Gambar 4 merupakan grafik curah hujan bulanan yang menunjukkan penurunan curah hujan selama 3 tahun (2017-2019).

Berdasarkan Gambar 5 diketahui bahwa sebaran hotspot per tahun dan jumlah hotspot per bulan di Tanjung Jabung Timur menunjukkan peningkatan jumlah hotspot dari tahun 2017 sebanyak 50 titik, tahun 2018 sebanyak 38 titik dan tertinggi pada tahun 2019 dengan total 1437 titik.

\section{Kelembapan Udara, Suhu Udara, Curah Hujan, dan Hotspot}

Musim kemarau pada tahun 2019 cenderung lebih panjang dibandingkan tahun sebelumnya dan menyebabkan kekeringan yang melanda sebagian besar wilayah Indonesia. Hal ini tampak pada kekeringan akibat rendahnya curah hujan pada periode musim kemarau dari bulan Juli hingga Oktober 2019.

Kondisi tersebut menyebabkan lahan gambut menjadi kering dan sangat mudah terbakar, sehingga jumlah hotspot di tahun 2019 lebih tinggi dibandingkan dua tahun sebelumnya (Gambar 5). Peningkatan drastis

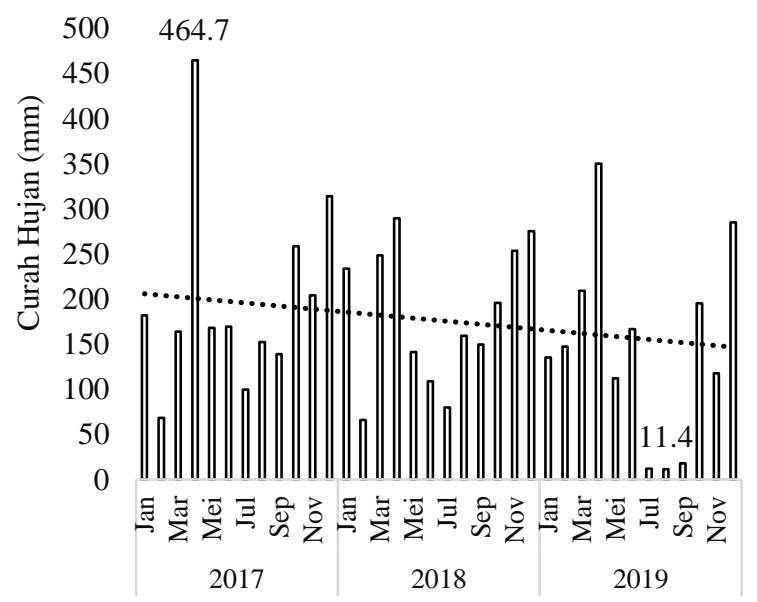

Gambar 4 Curah hujan bulanan Tanjung Jabung Timur tahun 2017-2019

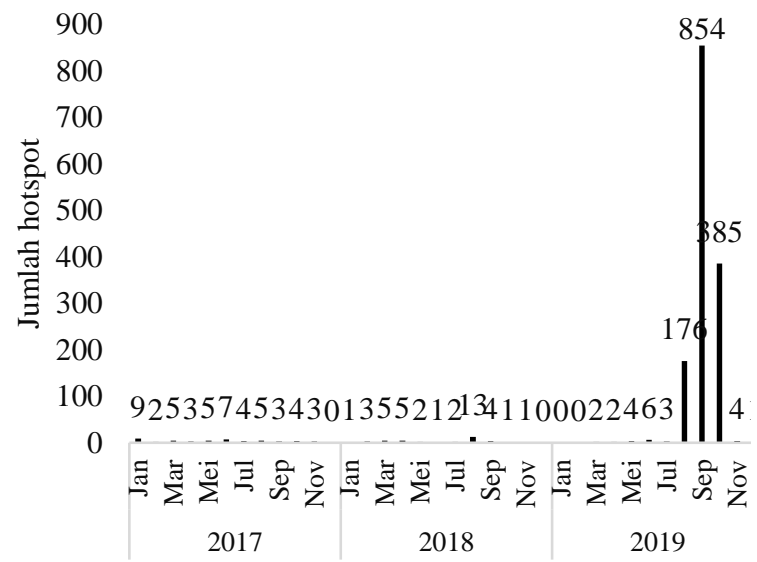

Gambar 5 Jumlah hotspot bulanan di Tanjung Jabung Timur tahun 2017-2019 jumlah hotspot terlihat pada bulan Agustus 2019 dengan terdeteksinya 176 titik kemudian meningkat menjadi sebanyak 854 titik pada bulan September 2019 yang merupakan bulan dengan hotspot terbanyak dan menjadikan 2019 sebagai tahun dengan total hotspot tertinggi.

WARSI (2019) melaporkan bahwa trend peristiwa kebakaran yang terjadi di Tanjung Jabung Timur pada kurun waktu sepanjang tahun 2019 adalah terjadinya peningkatan kejadian kebakaran pada bulan Agustus dan mencapai puncak pada bulan September 2019. Hal ini sesuai dengan analisis deskriptif terkait sebaran hotspot bulanan di Tanjung Jabung Timur pada tahun 2019 (Gambar 5) yang menunjukkan peningkatan jumlah hotspot dari bulan Juli sebanyak 3 titik menjadi 176 titik pada bulan Agustus dan semakin meningkat bulan September dengan total 854 titik yang kemudian menurun menjadi 385 titik bulan Oktober dan semakin menurun drastis hingga menjadi 1 titik pada bulan Desember.

Korelasi antara curah hujan dan hotspot memiliki hubungan yang rendah dengan nilai korelasi -0,297. Konotasi negatif menunjukkan hubungan antara curah hujan dan hotspot adalah berbanding terbalik, dimana penurunan curah hujan diikuti dengan peningkatan jumlah hotspot. Gambar 6 menunjukkan bulan Agustus 2019 merupakan bulan dengan curah hujan terendah sebesar 11,4 mm dan terjadi peningkatan jumlah hotspot menjadi 176 titik dari 3 titik pada bulan Juli 2019. Curah

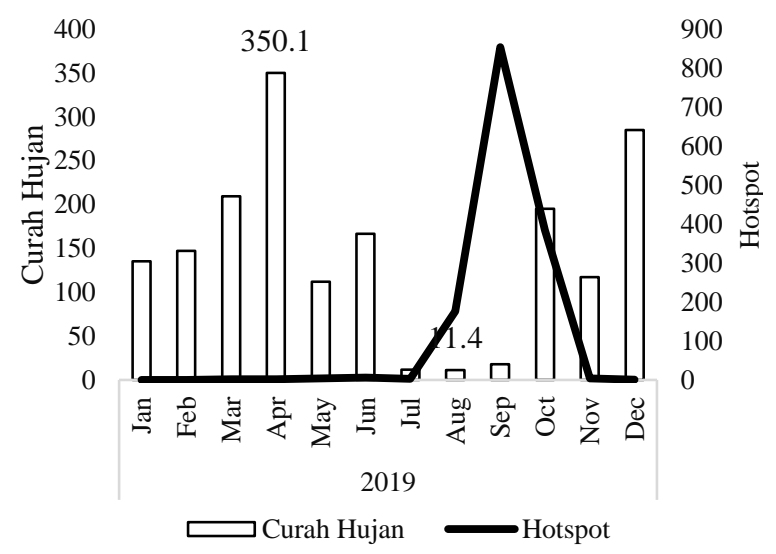

Gambar 6 Hubungan antara curah hujan dan hotspot di Tanjung Jabung Timur tahun 2017-2019

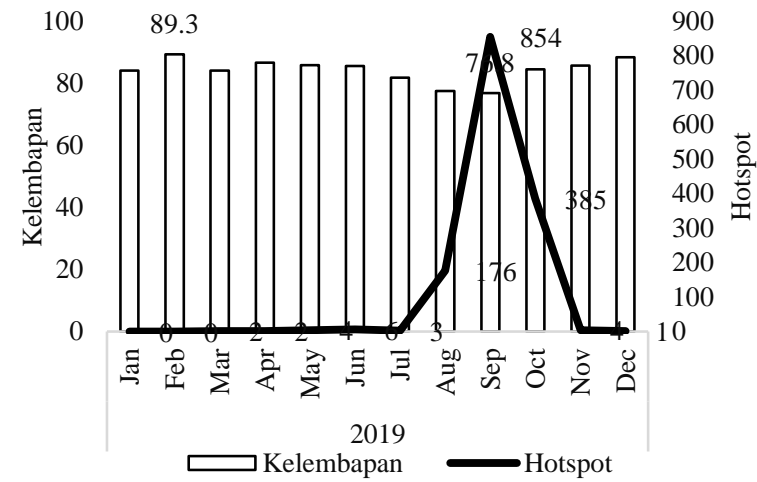

Gambar 1 Hubungan antara kelembapan dan hotspot di Tanjung Jabung Timur tahun 2017-2019 
hujan yang tidak mempengaruhi jumlah titik panas diduga terjadi karena peningkatan curah hujan yang tidak diikuti oleh kembali naiknya tinggi muka air (TMA) atau Groundwater Level (GWL) lahan gambut. Taufik et al. (2015) mengatakan bahwa kondisi gambut yang terdegradasi akibat pembukaan lahan dan pembuatan drainase, akan membuat air gambut mudah mengalir keluar sehingga gambut menjadi kering. Hal ini menunjukkan kondisi gambut yang sudah terdegradasi dan kehilangan kemampuan untuk menyerap dan menyimpan air (Putra et al. 2018).

Groundwater Level (GWL) telah digunakan sebagai indikator untuk memprediksi kejadian kebakaran (Usup et al. 2004, Wosten et al. 2008, Putra et al, 2008). Lebih dari 99\% kebakaran di areal ex-Lahan Gambut Sejuta Hektar (PLG) di Kalimantan Tengah terjadi ketika GWL berada di bawah permukaan tanah dengan periode puncak kebakaran dimulai pada pertengahan Agustus ketika curah hujan harian mencapai nilai minimum dan GWL menurun tajam. Kebakaran berulang di area PLG mengakibatkan penurunan kapasitas lahan gambut untuk menahan dan menyerap air, menurunkan tingkat GWL dan membuat area tersebut lebih rentan terhadap kebakaran, terutama di musim kemarau (Putra dan Hayasaka, 2011)

Nilai korelasi antara suhu udara dan jumlah hotspot adalah 0,217. Nilai korelasi menunjukkan hubungan berbanding lurus dan rendah antara suhu udara dan jumlah hotspot, dimana peningkatan suhu udara diikuti oleh peningkatan jumlah hotspot. Gambar 11 menunjukkan pada bulan Agustus 2019 merupakan bulan dengan suhu udara tertinggi yakni $27,6^{\circ} \mathrm{C}$ terjadi peningkatan jumlah hotspot. Itsnaini et al. (2017) menyatakan bahwa suhu udara mempengaruhi kekeringan suatu wilayah, terutama pada musim kemarau. Suhu udara tidak berpengaruh nyata terhadap hotspot, namun apabila curah hujan rendah ditambah dengan kondisi unsur iklim lain seperti suhu yang tinggi atau perubahan cuaca maka kebakaran mudah terjadi. Rentang suhu yang cenderung sempit dan kurang bervariasi menyebabkan tidak berpengaruh nyata terhadap hotspot.

Korelasi antara kelembapan dan hotspot memiliki hubungan yang cukup tinggi dengan nilai korelasi sebesar -0,569. Rentang bulan Agustus-September 2019 merupakan rentang bulan dengan tingkat kelembapan rendah dan pada rentang bulan yang sama jumlah hotspot mengalami kenaikan hingga mencapai puncaknya pada bulan September sebanyak 854 titik (Gambar 7). Hal ini sesuai dengan pendapat Vembrianto et al. (2015) bahwa kelembapan udara di dalam hutan sangat mempengaruhi pada mudah atau tidaknya bahan bakar untuk mengering yang berarti mudah tidaknya terjadi kebakaran.

Ketiga variabel mendukung satu sama lain terhadap jumlah hotspot dengan cara penurunan curah hujan diakibatkan kemarau yang lebih panjang pada tahun 2019. BMKG menyatakan kemarau tahun 2019 juga menunjukkan kondisi lebih kering dari musim kemarau tahun 2018, apabila curah hujan rendah dan kelembapan turun ditambah dengan kondisi unsur iklim lain seperti suhu yang tinggi atau perubahan cuaca maka kadar air pada lahan gambut rendah sehingga menyebabkan kebakaran mudah terjadi.
Kondisi tersebut diperlihatkan pada kejadian kebakaran di Kabupaten Tanjung Jabung Timur Jambi tahun 2019 dimana terjadi peningkatan kejadian kebakaran sejak bulan Agustus hingga mencapai puncak pada bulan September dan menurun pada bulan Oktober. Kondisi iklim pada bulan Oktober mengalami perubahan dimana terjadi peningkatan kelembapan, diikuti peningkatan suhu udara, dan penurunan curah hujan yang mengakibatkan penurunan jumlah hotspot. WARSI (2019) melaporkan bahwa terjadi kejadian kebakaran di Tanjung Jabung Timur sebanyak 64\% di lahan gambut pada periode tahun 2019. Lahan gambut mampu menyimpan air dalam jumlah banyak akan tetapi permukaannya cepat sekali mengering dan mudah terbakar saat musim kemarau. Sifat permukaan lahan gambut yang mudah kering dalam beberapa hari jika tidak terjadi hujan akan menjadikan daerah tersebut rawan terbakar saat memasuki musim kering (Prayoga et al. 2017).

\section{SIMPULAN DAN SARAN}

\section{Simpulan}

Analisis korelasi kelembapan udara, suhu udara, curah hujan terhadap hotspot di Kabupaten Tanjung Jabung Timur dalam kurun waktu 2017-2019 memperlihatkan bahwa ketiganya berpengaruh terhadap jumlah hotspot. Kelembapan merupakan variabel dengan nilai korelasi tertinggi, sebesar -0,569. Penurunan kelembapan udara diikuti dengan peningkatan jumlah hotspot. Kelembapan udara yang diikuti oleh penurunan curah hujan disertai terjadinya peningkatan suhu udara mulai bulan Juni sampai bulan September 2019 menyebabkan terjadinya peningkatan hotspot tertinggi sepanjang tahun 2017-2019 pada bulan September 2019 yang menyebabkan terjadi peningkatan kejadian kebakaran di Tanjung Jabung Timur, Jambi.

\section{Saran}

Perlu adanya studi terkait variabel iklim lainnya yang menyebabkan atau memicu kemungkinan terjadinya kebakaran gambut secara berkelanjutan.

\section{DAFTAR PUSTAKA}

Itsnaini N, Sasmito B, Sukmono A, Prasasti I. 2017. Analisis hubungan curah hujan dan parameter sistem peringkat bahaya kebakaran (SPBK) dengan kejadian kebakaran hutan dan lahan untuk menentukan nilai ambang batas kebakaran. Jurnal Geodesi Undip 6(2): 62-70.

Nurjanah S, Octavia D, Kusumadewi F. 2013. Identifikasi Lokasi Penanaman kembali Ramin (Gonystylus bancanuz Kurz) di Hutan Rawa Gambut Sumatera dan Kalimantan. Bogor (ID): FORDA.

Pemerintah Tanjung Jabung Timur. 2018. Gambaran Umum Kabupaten Tanjung Jabung Timur [internet]. [Diakses 2020 Mei 19]. Tersedia dari: 
https://tanjabtimkab.go.id/profil/detail/50/gambara n-umum-kabupaten-tanjung-jabung-timur.

Prayoga MBR, Yananto A, Kusumo DA. 2017. Analisis korelasi kerapatan titik api dengan curah hujan di pulau Sumatera dan Kalimantan. Jurnal Sains \& Teknologi Modifikasi Cuaca 18(1): 17-23.

Putra EI, Cochrane MA, Vetrita Y, Graham L, Saharjo BH. 2018. Determining Critical Groundwater Level to Prevent Degraded Peatland from Severe Peat Fire. in: IOP Conference Series: Earth and Environmental Science 012027. DOI: 10.1088/1755- 1315/149/1/012027

Putra EI, Hayasaka H, Takahashi H, Usup A. 2008. Recent Peat Fire Activity in the Mega Rice Project Area,Central Kalimantan, Indonesia. Journal of Disaster Research, 3 (5), 1-8.

Putra EI and Hayasaka H. 2011. The effect of the precipitation pattern of the dry season on peat fire occurrence in the Mega Rice Project area, Central Kalimantan, Indonesia. Tropics, 19 (4), 145-156.

Saharjo BH, Velicia WA. 2018. Peran curah hujan terhadap penurunan hotspot kebakaran hutan dan lahan di empat provinsi di Indonesia pada tahun 2015-2016. Jurnal Silvikultur Tropika 9(1): 24-30.

Syaufina L. 2008. Kebakaran Hutan dan Lahan di Indonesia: Perilaku Api, Penyebab dan Dampak Kebakaran. Malang (ID): Bayumedia Publishing.

Tambunan I. 2019. Pembalakan Liar di Kawasan Kebakaran Hutan. Kompas [internet]. [diakses
2020 Agustus 6]. Tersedia dari: https://kompas.id/baca/utama/2019/09/20/pembala kan-liar-di-kawasan-kebakaran-hutan/.

Taufik M, Setiawan BI, vanLanen HAJ. 2015. Agricultural and forest meteorology modification of a fire drought index for tropical wetland ecosystems by including water table depth. Agricultural and Forest Meteorology 203: 1-10.

Usup A, Hashimoto Y, Takahashi H, and Hayasaka H. 2004. Combustion and thermal characteristics of peat fire in tropical peatland in Central Kalimantan, Indonesia, Tropics, 14 (1), 1-19.

Vembrianto N, Yoza D, Sribudiani E. 2015. Karakteristik ekologi lokasi kebakaran hutan dan lahan di Desa Rantau Bais Kecamatan Tanah Putih Kabupaten Rokan Hilir. Jom Faperta 2(1): 1-8.

WARSI. 2019. Kerusakan Ekosistem, Jambi Rugi Lebih Rp 17 T [internet]. [Diakses 2020 September 17]. Tersedia dari: https://warsi.or.id/kerusakanekosistem-jambi-rugi-lebih-rp-17-t/.

Wosten JHM, Clymans E, Page SE, Rieley JO, Limin SH. 2008. Peat-water interrelationships in a tropical peatland ecosystem in Southeast Asia. Catena, 73, 212-224. 